\title{
The English Communication Needs of Music Students and ESP Curriculum Development at BA Level
}

\author{
${ }^{1}$ Bardha Gashi, ${ }^{2}$ Fatbardh Gashi \\ ${ }^{1,2}$ New Bulgarian University, Sofia, Bulgaria \\ "Haxhi Zeka" University, Peja, Kosovo
}

\begin{abstract}
This study investigates the communication needs of Music Students in English and their challenges faced during a Master course with professionals at European Summer Music Academy. The research instruments are two-stage surveys and observation of two groups of students at Faculty of Arts of "Haxhi Zeka" University. The results of the study show that English is one of the communication barriers of music students, and that the majority of them have difficulties in communicating in English with international musicians. Most English usage occurs in a Master course. The most difficult skills for Music students are found to be oral communication in English and listening comprehension. However, there are still very strong needs for further improvement in English communication. For the ESP courses, oral communication activities, especially in preparatory English Programs, are particularly needed. The ESP courses should connect with realworld practice and be relevant to actual needs of students. This study has significant implications for English for Music syllabus development.
\end{abstract}

Keywords: communication needs, English for music, master class, listening comprehension, syllabus development 


\section{Introduction}

Various types of programs have been established in Kosovo higher education institutions. The students of the Faculty of Arts can pursue their studies only full-time mode. Music programs usually require students to have previous education in music, especially, students of performing department. Study programs are now aimed at attaining international standards and certified accreditation by European agencies, such as the ENQA.

Most analyses of English language needs of musicians and curriculum studies focus on preexperience student groups, such as university students. This study investigates Music students' communication needs analysis and curriculum development of ESP, which is addressing the challenges and difficulties of musicians in a Master course. The study furthers the understanding of the diverse communication and learning needs of students, and of effective curriculum design, through empirical investigation.

\section{Literature Review}

2.1.Skills and Strategies

During its fourth phase of development, ESP has witnessed a radical change since no more attention was given to the surface of language' forms; the main focus was on thinking processes that govern language use. Hutchinson et al. (1987:13) argue that: "No need to focus closely on the surface forms of the language the focus should rather be on the underlying interpretive strategies, which enable the learner to cope with the surface forms".

Dudley-Evans et al (1998) move a step ahead where they associated the focus on skills with the idea of communicative language teaching and state that, these interests have grown and developed naturally from what they have labeled "functional-notional material." So while examining this phase, we may say that:

- Strategy analysis seeks to emphasize much more the learners' expectations for the way they should learn than what they want to learn. 
- Depending on the particular characteristics of a typical situation; there are priorities among skills, i.e., a skill which is emphasized in one situation such as reading is inappropriate for another situation, consequently, another skill will be more adequate such as writing.

In this regard, Dudley-Evans et al. (1998:24) maintain that: "in many situations, especially when the medium of instruction was not English, for example in Latin America, this meant a focus on reading”. In other situations it might involve a different skill, such as listening for international students embarking on academic courses in the UK. As an example of this approach, Dudley Evans et al. (1998) consider that the course which has been developed at Malaya University under the title of "Skills for learning", focuses primarily on the reading skill. ESP at this phase dealt with the thinking processes which imply the use of language aiming at developing learners' skills and strategies to acquire a second or a foreign language.

\subsection{The position of students who attend ESP courses}

ESP learners are often adult learners. They already have a background in English and seek to learn English for a "clearly utilitarian purpose" to meet specific target needs Mackay et al. (1978). It is common knowledge that although students spend 8 years studying English as a school subject, it may not be sufficient for them to achieve an intermediate level of proficiency in language.

The knowledge and usage of English that school leavers possess gives rise to concern. Students find it very hard to cope with learning ESP basically because of the lack of the General English skills. The ESP course introduces learners to English for Music, i.e. the kind of language they will face in their future profession. Learners have to master terms used in music, to be able to comprehend formal professional text and authentic recordings of lectures and produce formal pieces of writing as well as be able to make professional presentations and participate in discussions on music issues. The natural question that occurs is why school leavers do not possess adequate language skills, and an attempt has been made to tackle this question. In most cases, those learners are supposed to have an intermediate or advanced level. Yet, in this case, the use of authentic materials as a component of the ESP course adopted or adapted is inevitable. 
The second feature of the ESP course as mentioned before by Carver (1983) is: purpose related orientation, i.e., the situation of communicative tasks required by the target situation. According to Carver (1983), the main aim of the ESP course is to enable learners to become communicatively competent in the target field through note-taking, conducting researches and presenting oral tasks.

The last feature as viewed by Carver (1983) is self-direction. It is defined as: "turning learners into users". Therefore, it is crucial for the ESP practitioner to base his course on a Needs Analysis procedure at the first step, while in the second step she is invited to encourage her students to decide what, when and how to study, that is, displaying a certain level of autonomy or freedom. In this respect, Kennedy et al. (1984:141) write: "A prime concern for the teacher is to enable a student to become more and more autonomous in his learning as the course goes on".

\subsection{Learners' Expectations towards ESP Courses}

The attitudes of the film directing students towards the English language often leave much to be desired. For some students, having to learn English is seen as mere additional, even unnecessary, hurdle in the way of obtaining their diplomas. Consequently, the learner's attention and interest in learning the language is somewhat hostile rather than co-operative. Such negative attitudes to the language can be explained in at least two ways.

Firstly, it is probably natural for a student of arts to be disappointed, or even frustrated, upon discovering that English is an indispensable part of his academic career in the university. After all, for many who might have found English courses in the secondary school inadequate?

English a tough subject, being admitted into the university might have brought a sigh of relief at the completion of secondary education. For such students, therefore, the mere mention of English as a compulsory subject could evoke anger and revulsion, particularly so when English is as important as other Film Directing or music courses or as core subjects the learner is taking.

Secondly, needs analysis is not unique to ESP but it is essential in helping the teacher to define the specific sets of skills, texts, linguistic forms, and communicative practices that a particular 


\section{1-23 February, $2020 \quad$ Rome, Italy}

group of learners must acquire. The students' level of language knowledge is essential as teachers nowadays face the challenge of working with multilevel classrooms or "mixed-ability" classes.

As shown in the figure below, ESP is defined based on: needs, requirements, wants, specificity and purpose of the students.

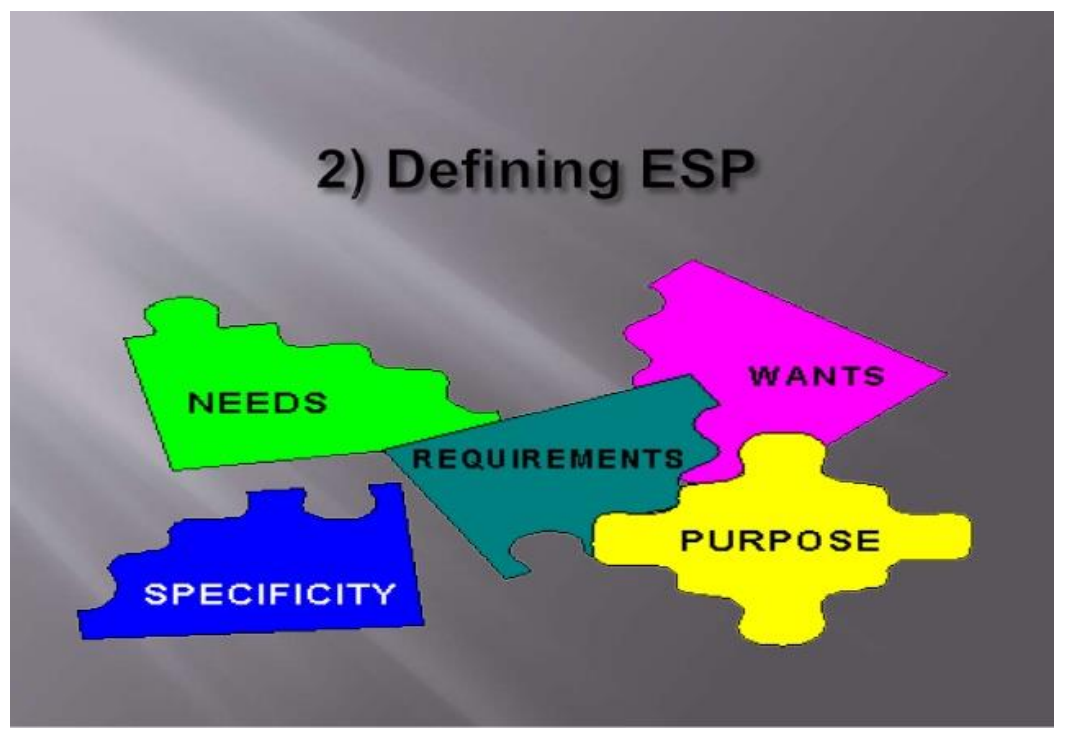

Figure 1. Defining characteristics of ESP

Students arrive in ESP learning environments with a varied background of linguistic knowledge and this leads to a new hardship, teachers getting engaged in a differential teaching process, so as to satisfy students' needs and necessities. Penny Ur (n.d.) identifies a set of problems that are generally defining for large heterogeneous classes. The set of questions reunites them all (discipline, correcting written assignments, interest, effective learning for all, materials, individual awareness, participation) under the same umbrella. Teaching problems in large heterogeneous classes and the age of the students is also important, classes being presently made up of adults ranging in age from 18 to 40 or more. This fact can bring about serious consequences upon the way course designers organize their instructional process, due to the fact that "people of different ages have different needs, competences and cognitive skills". For those that have just graduated from high school or secondary school and choose to continue their studies at an academic level, 
the process of learning would not be a huge challenge. The difficulty appears for the other categories of learners who might have lost the initial ability to study, in time. According to Harmer (n. d.) adult learners can exhibit some traits that can easily make learning and teaching problematic. Thus, they might be critical of teaching methods, being sometimes reluctant to engage in roleplaying activities, or scenarios that might put them in an uncomfortable position; they may feel anxious or under-confident about learning a language and sometimes worry about their intellectual capacities. All these elements must be thought over carefully when engaging in the process of course elaboration, always keeping in mind the fact that ESP focuses upon improving specific strategies rather than learning general language.

To sum up, ESP courses hold specific characteristics which may differ from other courses. Learners' needs, wants, and lacks constitute the primary step in the process of needs analysis upon which it could be possible for the language teacher, later on, to design an adequate and effective course.

\section{Research Methodology}

This study is based on a case of a Master class offered at a public university during European Summer Music Academy in the western Kosovo. In this case, the study aims can be summarized as follows, based on the program syllabus: To enhance students' English comprehension, use and communicative ability in the international music contexts; To enable students to understand the standard and original English use and expressions of music context; To enable students to further understand musical terms in a real context; To enable students to master basic functions and skills in communication with professional in English; To identify difficulties and needs in order to improve the ESP syllabus for the department of Artistic Education in Performing. The data collection methods of this case study are mainly qualitative including a survey and a class observation. 


\subsection{Research Questions}

The main research questions are as follows:

- Research Question 1: What are the main communication needs of Music students (instrumentalists) in the Master class context?

- Research Question 2: Based on the differences in needs, how can ESP instructors design the English for Music course more effectively?

\section{Data Analysis}

In the data analysis stage, the researchers conducted a content analysis of the communication during a Master class at the Faculty of Arts, and the main needs and lacks are identified. It has also been calculated the frequency of the responses and the percentage of participants, which are then presented in charts and tables. The various communication needs of students, and their perceptions of Music English in real content practice have been highlighted. The musical terms provided in Albanian are translated into English by the researcher. To ensure the confidentiality of the participants' identity, pseudonyms are used in the study.

\subsection{Main Communication Challenges of Music Students during the Master Course}

Effective Music English Curriculum Design For best practice of English teaching, more than $50 \%$ of the participants indicated the necessity for expatriate learning. There were also oral communication and classroom interaction, group discussion, and writing instruction. More than $80 \%$ mentioned the needs of connecting with real-world practice. The results of the study confirm the need for English speaking best practice theories in the literature through empirical evidence. For characteristics of English for Music students, more than one third of the participants mentioned practical teaching content, which is relevant to the students' communication needs. The teachers should integrate more music knowledge into their teaching. There are also the unique, humorous, and relaxing teaching styles. Teachers should have interaction with students. The constraint factors for effective English teaching include the class size and time limitations. Through analyzing real- 
world cases, the musicians can develop both oral communication skills and comprehension of spoken English. The teachers and students should cooperate. For those factors which constrain teaching effectiveness, they should be adjusted for optimizing the learning outcomes. For topics of further English courses, more than $48 \%$ hoped to take further English for Music courses.

\subsection{Findings and Discussion}

The participants experienced difficulties in English communication, as shown in Table 1. More than $40 \%$ of the participants mentioned various difficulties in using vocabulary and English expressions effectively in English communication, including professional music terms.

The two-stage study for the communication needs of Music students during a Master class at the European Summer Music Academy 2019, held in two cities in Kosovo, presented the communication difficulties of musicians in an English speaking context.

The chart below shows the communication skills of the students who attended the course.

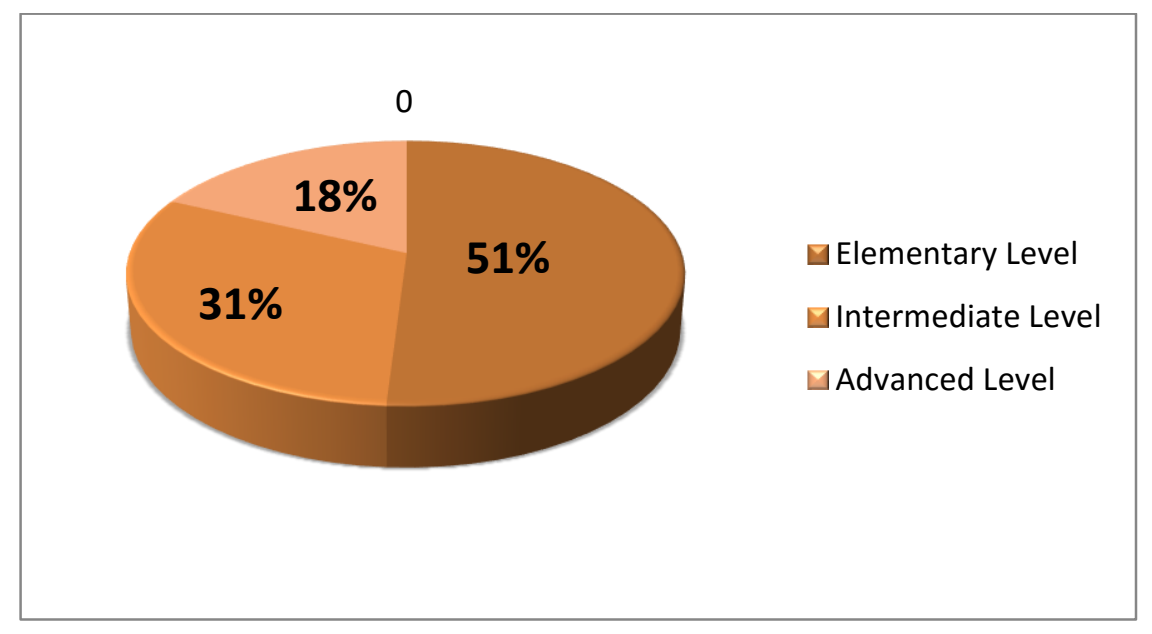

\section{Chart 1. Department of Artistic Education in Performing}

When the participants answered the question "What components of language proficiency should be given attention in the ESP classroom?" they mentioned that vocabulary development, grammar practice, speaking and writing skills would be given enough time and attention in the classroom. However, the survey showed that students wish to practice their listening 


\section{1-23 February, $2020 \quad$ Rome, Italy}

comprehension more, especially in the context of face-to-face communication with international professionals. It shows that at this stage of instruction (second year-clarinet players) find the ability to communicate across professional boundaries more relevant than communication within discourse boundaries of their future job. It is evident in the fact that the majority of the students were not satisfied with the amount of time (two semesters) devoted to English lessons.

While, the analysis as well as the interpretation of observation is presented as follows:

a. It is adequate but should include more communication: 6

b. It is adequate to a great extent: 2

c. It is not very adequate: 6

d. It is not adequate: 3

e. Total of Opinions: 17

Table 1. Results from master class observation 


\section{1-23 February, $2020 \quad$ Rome, Italy}

\begin{tabular}{|l|c|c|c|c|l|}
\hline Component & Too much time & Enough time & Little time & No time & Total \\
\hline $\begin{array}{l}\text { Professional } \\
\text { vocabulary }\end{array}$ & 28 & 25 & 4 & 3 & 60 \\
\hline $\begin{array}{l}\text { General English } \\
\text { vocabulary }\end{array}$ & 15 & 8 & 25 & 12 & 60 \\
\hline $\begin{array}{l}\text { Listening } \\
\text { comprehension } \\
\text { (face-to-face } \\
\text { communication } \\
\text { with } \\
\text { professionals) }\end{array}$ & 0 & 2 & 55 & 3 & 60 \\
\hline $\begin{array}{l}\text { Listening } \\
\text { comprehension } \\
\text { (watching } \\
\text { video) }\end{array}$ & 5 & 29 & 24 & 2 & 60 \\
\hline $\begin{array}{l}\text { Grammar } \\
\text { practice }\end{array}$ & 38 & 5 & 17 & 0 & 60 \\
\hline Speaking skills & 14 & 12 & 30 & 4 & 60 \\
\hline Writing skills & 21 & 11 & 25 & 3 & 60 \\
\hline
\end{tabular}

Table 2. What are the main areas you wish the ESP classes cover

\section{Conclusion}

This study reports a two-stage investigative study for the English communication needs of 17 musicians, currently studying at the Faculty of Arts of "Haxhi Zeka" University, and their perceptions of effective curriculum design. For main communication and learning needs of music students, it can be concluded for this study context that there is not extensive English use in the English (ESP) classes, therefore, the students and that the majority of them have difficulties communicating in English in a real context, such as at Master classes. Less English usage occurs in face-to-face interaction with international professionals, where there is more professional communication, using limited Italian Music terms, than oral communication in English. There is also more external than internal communication in English. The most difficult skills for musicians are found to be oral communication and listening comprehension, partly due to the lack of opportunities to use English in the classroom. However, there are still very strong needs for further improvement in English communication. For more effective English for Specific Purposes 


\section{1-23 February, $2020 \quad$ Rome, Italy}

curriculum design, oral communication activities, particularly with expatriate teachers, are particularly needed, along with other communicative approaches and multimedia learning resources. Through taking effective ESP courses, the students of Faculty of Arts should gain English communicative competence and also better career opportunities in the future.

\section{Acknowledgments}

The authors would like to express heartfelt thanks to the participants for their helpful contributions to the study. The authors are also grateful for the expert comments from professional musicians who took part at the Master classes during European Summer Music Academy 2019.

\section{References}

Anthony, L. (1997). English for Specific Purposes: What does it mean? Why is it different? http://www.antlab.sci.waseda.ac.jp/abstracts/ESPartic le.html September 2009.

ALTE, (2018). Guidelines for the Development of Language for Specific Purposes Tests Retrieved from: https://www.alte.org/resources/Documents/6093\%20LSP\%20Supplement\%20-\%20WEB.pdf

Basturkmen, H. (2006). Ideas and Options in English for Specific Purposes. London, Mahwah, New Jersey: Lawrence Erlbaum Associates.

Carver, D. (1983). Some Propositions about ESP. The ESP Journal, 131-135

Common European Framework of Reference for Languages (CEFR). Retrieved from: https://www.coe.int/en/web/common-european-framework-reference-languages

Dudley-Evans, T \& St John, M. (1998). Developments in English for Specific Purposes: A MultiDisciplinary Approach. Cambridge: Cambridge University Press.

European Summer Music Academy 2019, Peja and Prishtina, Kosovo.

Hutchinson, T \& Waters, A. (1987) English for Specific Purposes: A Learning Centred Approach. Cambridge: Cambridge University Press.

Kennedy, C, H \& Bolitho, R. (1984). English for Specific Purposes. London: Mc Millan Press, Ltd.

Kennedy, C. (1983). An ESP approach to EFL/ESL teacher training. The ESP Journal, Vol2, Issue 1: 7385 .

Mackay, R \& Mountford, A. (1978). English for Specific Purposes: A Case Study Approach. London: Longman. 